\title{
Law Enforcement against Policies Who Breached the Code of Conduct
}

\author{
Alvi Syahri *) \\ ${ }^{*}$ ) Student of Master of Law, Universitas Islam Sultan Agung Semarang and Police, \\ Members of the Indonesian National Police, email: alvisyahri69@gmail.com
}

Abstract. The purpose of this research to find out and analyze law enforcement against police officers who violate the code of ethics in carrying out their duties at Central Java Police, obstacles and solving obstacles. This study uses a sociological juridical approach with descriptive analysis research specifications. The data used are primary data and secondary data obtained through interviews and literature study. The data analysis method used is qualitative analysis. Furthermore, based on the research results it can be concluded: Law enforcement against police officers who violate the code of ethics in carrying out their duties at the Central Java Regional Police refers to Act No. 2 of 2002 concerning the Police, Government Regulation of the Republic of Indonesia Number 2 of 2003 concerning Disciplinary Regulations for Members of the National Police and Regulation of the Chief of Police No. Pol. 14 of 2011 concerning the Professional Code of Ethics for the State Police of the Republic of Indonesia. Several factors that hinder law enforcement against unscrupulous police officers who violate the code of ethics are divided into internal factors: Leaders who have not fully paid attention to the implementation of disciplinary law enforcement duties for Polri members, level of discipline, awareness and compliance of Polri members with binding disciplinary regulations and applies to him is still relatively low so that disciplinary violations keep happening, Polri's disciplinary law enforcement often appears to lack transparency. External factors: Lack of public awareness in conducting supervision and complaints when there are people who violate them. Keywords: Law Enforcement; Police Officers; Offenses; Code of Ethics.

\section{Introduction}

Law enforcement must apply equally to all Indonesian citizens without discrimination. Law enforcement is at the same time an indicator of a rule of law. Therefore, in the context of advancing computer technology in Indonesia, the issue of law enforcement must receive priority. ${ }^{1}$

Law enforcement is an effort to uphold or function legal norms in a clear manner as a guideline for behavior in traffic or legal relations in public and state life, to guarantee and ensure the enforcement of the law, if necessary; law enforcement officials are permitted to use force. ${ }^{2}$

Law enforcement aims to obey the law. Community obedience to the law is caused by three things, namely: ${ }^{3}$

\footnotetext{
${ }^{1}$ https://sasmitasmansa.wordpress.com/2011/12/07/pengertian-penegakan-hukum, downloaded on Wednesday $20^{\text {th }}$ November 2019

${ }^{2}$.https://www.suduthukum.com/2016/10/pengertian-penegakan-hukum.html, downloaded on Wednesday $20^{\text {th }}$ November 2019

${ }^{3}$ Sri Endah Wahyuningsih, 2017 Penegakan Hukum Pidana Terhadap Pengguna Narkoba di Polda Jateng, Journal
} 
- Fear of sinning

- Fear because the power of the ruler is related to the imperative nature of the law

- Fear of being ashamed of sinning 4

Through law enforcement, the law becomes a reality. In enforcing the law, there are three elements that must always be considered, namely: legal certainty, benefit, and justice. $^{5}$

Of course, the aforementioned objectives will not be realized if they are not carried out with high dedication, discipline and professionalism from the members of the National Police themselves to try to carry out their assigned duties properly and responsibly. Starting from the importance of discipline for members of the Police as law enforcers.

Every law enforcement personnel must be bound by rules or laws as a reference in acting. The rules that bind the National Police include Act No. 2 of 2002 concerning the State Police of the Republic of Indonesia, Government Regulation Number 2 of 2003 concerning Disciplinary Violations of Members of the State Police of the Republic of Indonesia, Regulation of the Chief of Police Number 14 of 2011 concerning the Professional Code of Ethics for the State Police of the Republic of Indonesia. However, the many regulations that bind Polri do not guarantee the growth of a professional spirit in some Polri members, because there are still many things that violate the police professional code of ethics. Where on the one hand the police are expected to be law enforcers, but on the other hand the police commit violations against the police ethics profession.

It is further stated in Article 34 of Act No. 2 of 2002, namely that: ${ }^{6}$

- The attitude and behavior of Indonesian National Police officials are bound to the Professional Code of Ethics for the Indonesian National Police.

- The Professional Code of Ethics for the State Police of the Republic of Indonesia can serve as a guideline for the carrying out of other police functions carry out tasks in accordance with the laws and regulations in force in the environment.

- Provisions regarding the Professional Code of Ethics for the State Police of the Republic of Indonesia are regulated by a Decree of the National Police Chief.

Polri's indiscipline and unprofessionalism will greatly impact law enforcement or disclosure of crimes that occur in society. The condition of the weakening of discipline and professionalism of members of the National Police that is currently occurring is often the talk of the wider community. In reality that happened at Central Java Police, there were some unscrupulous members of the police who acted the opposite and were not in accordance with the professional ethics of the police or in the sense of the word that some police committed violations of the police professional code of ethics. Police ethics certainly have legal consequences for unscrupulous members.

Criminalization is the imposition of punishment / sentencing as a legitimate effort according to law to impose on someone or more in the form of suffering through a

\footnotetext{
${ }^{4}$ Sri Endah Wahyuningsih, 2013Prinsip-Prinsip Individualisasi Pidana dalam Hukum Pidana Islam, Semarang: Diponegoro University Publishing Agency

${ }^{5}$.Satjipto Rahardjo, 1996, Ilmu Hukum, Bandung: PT. Citra Aditya Bakti, p 181

${ }^{6}$ Law Number 2 of 2002 concerning the Indonesian National Police
} 
criminal justice process which, if proven legally and convincingly, has committed a criminal act. ${ }^{1}$

Legal violations committed by unscrupulous members of the Police at Central Java Police will be prosecuted in accordance with applicable regulations, namely Act No. 2 of 2002 and Regulation of the Chief of Police No. Pol. 14 of 2011 concerning the Professional Code of Ethics for the State Police of the Republic of Indonesia.

Based on the description that has been mentioned above, the authors are interested in knowing more about the implementation of police code of ethics through writing a thesis with the title: "Law Enforcement Against Policies Who Breached The Code Of Conduct In Implementing Their Duties In The Central Java Police".

\section{Research Methods}

The approach method used is juridical empirical, which is a way to solve research problems by examining secondary data first and then continuing research on primary data in the field. Research specifications, namely descriptive analysis by focusing on the problem then processed and analyzed to draw conclusions ${ }^{7}$. Kind of data, namely primary data and secondary data. Sources of data are interviews and literature studies. The data collection method used is Primary data by conducting interviews Secondary data: relevant literature studies, either in the form of theories or opinions from experts documented in literature ${ }^{8}$. Data analysis method, namely qualitative analysis by describing data in the form of regular, logical and effective sentences. ${ }^{9}$

\section{Results And Discussion}

\subsection{Law Enforcement Against Police Officers Who Violate The Code Of Ethics In Carrying Out Their Duties At Central Java Police}

Act No. 2 of 2002 concerning the State Police of the Republic of Indonesia provides an explanation of the role, function and main duties of the National Police, namely that the Indonesian National Police is a state instrument that plays a role in maintaining public security and order, upholding the law, and providing protection, protection and service to the community in the framework of maintaining domestic security (Article 5 (1)). The function of the police is one of the functions of the state government in the field of maintaining security and public order, law enforcement, protection, protection, and services to the public [Article 2]. The National Police of the Republic of Indonesia aims to realize domestic security which includes maintaining security and public order. Orderly and upholding the law, the implementation of protection,

\footnotetext{
${ }^{1}$ Sisno Pujinoto, et.all, "Juridical Analysis Of Application Of Forgiveness (Rechterlijk Pardon) As A Basis Of Judge Consideration In Deciding The Criminal ", inJournal of Daulat Hukum Volume 3 Issue 2, June 2020,http://jurnal.unissula.ac.id/index.php/RH/article/view/10085, Thing. 308.

${ }^{7}$ Saifuddin Azwar, 2014, Metode Penelitian, Yogyakarta: Pustaka Pelajar, p. 7

${ }^{8}$ Soerjono Soekanto and Sri Mamudji, 1985, Penelitian Hukum Normatif, Suatu Tinjauan Singkat, Jakarta: Raja Grafindopersada, p.66.

${ }^{9}$ Bambang Waluyo, 2002, Penelitian Hukum dalam Praktek, Jakarta: Sinar Grafika, p.78.
} 
Efforts to enforce discipline and the Police Code of Ethics are urgently needed in order to realize the implementation of the assigned duties and achieve Polri's professionalism. It is highly unlikely that law enforcement can run well, if the law enforcer itself (Polri) is not disciplined and unprofessional. The indiscipline and unprofessionalism of the National Police will greatly impact law enforcement or disclosure of crimes that have occurred in society.

The aforementioned deviation in the behavior of Polri members is a violation of the disciplinary regulations of Polri members as stipulated in the Republic of Indonesia Government Regulation Number 2 of 2003 concerning Disciplinary Regulations for Polri Members and Chief of Police Regulation No. Pol. 14 of 2011 concerning the Professional Code of Ethics for the State Police of the Republic of Indonesia.

Efforts to enforce discipline and the Police Code of Ethics are urgently needed in order to realize the implementation of their assigned duties and achieve Polri's professionalism. It is very unlikely that law enforcement can run well, if the law enforcer itself (Polri) is not disciplined and unprofessional. Polri's indiscipline and unprofessionalism will greatly impact law enforcement or disclosure of crimes that occur in society.

Members of the State Police of the Republic of Indonesia are civil servants of the State Police of the Republic of Indonesia. As civil servants, the requirements for the appointment and dismissal of Polri members are bound by the prevailing laws and regulations within the Republic of Indonesia National Police. With regard to the issue of dismissing Polri members from the Indonesian National Police Service, the following provisions apply:

- Dismissal with Respect (PDH), if: reach the retirement age limit; special considerations for the interests of the agency; does not meet the physical and / or spiritual requirements; died, died, died or was missing in service.

- Disrespectful Termination (PTDH), if:

- Committing Crime: is sentenced to imprisonment based on a court decision which has permanent legal force and according to the consideration of the competent official cannot be retained to remain in the service of the State Police of the Republic of Indonesia; it is found out that after giving false and / or untrue information when registering as a candidate for member of the Indonesian National Police; illegally carrying out business or activities aimed at changing Pancasila, engaging in movements, or carrying out activities against the state and / or the Government of the Republic of Indonesia. Disrespectful dismissal as referred to above is carried out after going through a session of the Commission on Professional Code of Ethics of the Indonesian National Police;

- To violate the oath / promise of a member of the State Police of the Republic of Indonesia, oath / promise of office, and / or the Professional Code of Ethics of the State Police of the Republic of Indonesia. This termination was carried out after going through a session of the Commission on Professional Ethics of the Indonesian National Police;

- Leave their duties illegally within more than 30 (thirty) consecutive working days; or commit acts and behaves that can harm the Police service; or commits suicide with the intention of avoiding investigation and / or lawsuits or dies as a result of 
a criminal act he has committed; or become members and / or administrators of political parties. This termination was carried out after going through a session of the Commission for Professional Ethics Code of the State Police of the Republic of Indonesia.

Research conducted by the author in the jurisdiction of the Central Java Regional Police, that there are violations committed by members such as disciplinary violations such as members who are often late to work and there are members who commit criminal acts of using drugs. So in enforcing these persons refers to Act No.2 of 2002 concerning the Police, Government Regulation of the Republic of Indonesia Number 2 of 2003 concerning Disciplinary Regulations for Members of the Police and Regulation of the Chief of Police No. Pol. 14 of 2011 concerning the Professional Code of Ethics for the State Police of the Republic of Indonesia. Members, who commit drug use violations, after a code of ethics trial, are disrespectfully removed from membership and given criminal sanctions, in accordance with applicable regulations.

According to an interview the author conducted with Brigadier Deni Widodo, Bamin Urbinetika Subbidwabprof Bidpropam Central Java Police, law enforcement against police officers who violate the code of ethics in carrying out their duties at the Central Java Regional Police through the implementation mechanism of the code of ethics which refers to Perkap No. 14 of 2011 on code of ethics and Perkap No. 19/2012 concerning the Work Composition of the Code of Ethics. ${ }^{10}$

\subsection{Obstacles In Law Enforcement Against Police Officers Who Violate The Code Of Ethics In Carrying Out Their Duties At The Central Java Regional Police}

Several factors that hinder law enforcement against individual police officers who violate the code of ethics, are divided into internal factors and external factors which are described as follows:

- Internal factors: There are still among the unit leaders as Ankum who have not fully paid attention to the implementation of disciplinary law enforcement duties for Polri members, including the provincial police officers. In addition, psychological factors for the leadership as Ankum to sentence PTDH (Disrespectful Dismissal) for members who violate criminal acts and the National Police Code of Ethics, taking into account the families concerned; The level of discipline, awareness and compliance of Polri members with binding disciplinary regulations that apply to them are still relatively low so that disciplinary violations continue to occur; Polri's disciplinary law enforcement often appears to lack transparency, making it difficult for the public to carry out a supervisory function. In addition, there is often reluctance by examiners to examine members of the police who have committed crimes because of the sense of solidarity between police officers.

- External factors: The welfare of Polri members has not been felt, which has led to the growth of illegal acts by members of the police. One of the motives of several police officers who committed criminal acts was the economy and basic needs which were increasing day by day; Lack of public awareness in conducting

\footnotetext{
${ }^{10}$ Interviewed with Brigadir Deni Widodo, Bamin Urbinetika Subbidwabprof Bidpropam Polda Jateng, $16^{\text {th }}$ August 2020
} 
supervision and complaints of negative behavior by police officers. There is fear or pessimism that crimes committed by police officers will be processed fairly According to the interview the author conducted with Brigadier Deni Widodo, Bamin Urbinetika Subbidwabprof Bidpropam Central Java Police ${ }^{11}$, apart from the aforementioned obstacles there are also obstacles encountered, namely at the Polres level there is no organization or structure like in Polda. Cases that occur in the Polda jurisdiction include code violations. Ethics that occur, namely: Immoral crime; Disersion (leaving service for more than 30 consecutive days); Unprofessionalism in carrying out their duties

\subsection{Resolving Barriers To Law Enforcement Against Police Officers Who Violate The Code Of Ethics In Carrying Out Their Duties At The Central Java Regional Police}

Resolving barriers in law enforcement against police officers who violate the code of ethics in carrying out their duties at the Central Java Regional Police, the superiors in the police, in this case the Chief of Police or the Chief of Police or the Chief of Police, pay more attention in the form of pressure on his subordinates, so that the noble values of the police can be embedded. every member of the police, so they feel reluctant to commit irregularities which lead to criminal acts that tarnish the image of the police, in which the duty of the police should be to provide security, protection, to the wider community.

An essential element for realizing law enforcement is to obtain legal certainty, justice and benefits from law enforcement. The law enforcement process can run effectively if it is in the form of a chain of several processes that cannot be separated.

Leaders can provide guidance and guidance to members so that they can improve their performance. So that there is no overlapping and blaming each other on the occurrence of a situation in the strata of community life, moreover it happens within the body and body of the police. When each party and related institution can see and develop any existing deficiencies, it is believed that there will be no fraud, and then there can be equality in the performance of every state servant, especially in terms of the performance of the members of the police.

The steps taken by the Central Java Regional Police to reduce the occurrence of violations or criminal acts for their members, namely that every morning rally is always given directions or advice so that they don't ever try to violate or in their Javanese language deviate, then In every spiritual activity there are always insights that do not act fraudulently and do not try to occasionally commit or have the intention of committing violations, then the regulations are always socialized, especially regarding the police chief regulations and disciplinary regulations, which are always in a certain time of change of renewal, so always be socialized.

Through these actions, it is hoped that it can reduce a little so that the police do not commit or try to commit criminal acts in any way and in any way, thus causing harm not only to him, but also to his family and closest people, in this case. The community is also expected to be able to provide assistance indirectly, namely by monitoring and

${ }^{11}$ Ibid. 
filing complaints in the event of arbitrary actions by unscrupulous members of the police and not supporting the police to commit fraud.

\section{Closing}

\subsection{Conclusion}

Law enforcement against police officers who violate the code of ethics in carrying out their duties at the Central Java Regional Police refers to Act No.2 of 2002 concerning the Police, Government Regulation of the Republic of Indonesia Number 2 of 2003 concerning Disciplinary Regulations for Members of the National Police and Regulation of the Chief of Police No. Pol. 14 of 2011 concerning the Professional Code of Ethics for the State Police of the Republic of Indonesia. Several factors that hinder law enforcement against unscrupulous police officers who violate the code of ethics are divided into internal factors and external factors which are described as follows: Internal factors: There are still among the unit leaders as Ankum who have not fully paid attention to the implementation of disciplinary law enforcement duties. Polri members including Polri officers, the level of discipline, awareness and compliance of Polri members with binding disciplinary regulations that apply to them are still relatively low so that disciplinary violations continue to occur, the enforcement of disciplinary laws for Polri members often seems less transparent. External factors: Lack of welfare of Polri members and Lack of public awareness in conducting supervision and complaints when there are people who violate them. The steps taken by the Central Java Regional Police to reduce the occurrence of violations or criminal acts for their members, namely that every morning rally is always given directions or advice so that they don't ever try to violate or in their Javanese language deviate, then In every spiritual activity there are always insights that do not act fraudulently and do not try to occasionally commit or have the intention of committing violations, then the regulations are always socialized, especially regarding the police chief regulations and disciplinary regulations, which are always in a certain time of change of renewal. , so always be socialized.

\subsection{Suggestions}

For the Police, so that a regulation of the Police Professional Code of Ethics can be implemented properly, the Police should further increase the performance monitoring of its members in ways, such as providing guidance in accordance with the profession, emphasizing moral values in each individual so that they behave in accordance with the professional code of ethics. Attached to each member of the Police and practice the basis of the police so that there is no violation of the professional code of ethics again. For the Community It is hoped that the public can better understand how the mechanism for handling Polri members who commit criminal offenses and work discipline, so that the public knows that law enforcement officers can be dealt with firmly and the punishment is much heavier than the general public if they commit an offense. 


\section{Bibliography}

Journal

Sisno Pujinoto, et.all, "Juridical Analysis Of Application Of Forgiveness (Rechterlijk Pardon) As A Basis Of Judge Consideration In Deciding The Criminal ", in Journal of Daulat Hukum Volume 3 Issue 2, June 2020, http://jurnal.unissula.ac.id/index.php/RH/article/view/10085

Indah Lestari and Sri Endah Wahyuningsih, 2017, "Penegakan Hukum Pidana Terhadap Pengguna Narkoba di Polda Jateng", in Journal Khaira Ummah

Website

https://sasmitasmansa.wordpress.com/2011/12/07/pengentuk-penegakan-hukum, downloaded on Wednesday, November $20^{\text {th }}, 2019$

https://www.suduthukum.com/2016/10/pengentuk-penegakan-hukum.html, downloaded on Wednesday, November $20^{\text {th }}, 2019$

Books

Bambang Waluyo, 2002, Penelitian Hukum dalam Praktek, Jakarta: Sinar Grafika

Sri Endah Wahyuningsih, 2013, Prinsip-Prinsip Individualisasi Pidana dalam Hukum Pidana Islam, Semarang: Diponegoro University Publishing Agency

Satjipto Rahardjo, 1996, Ilmu Hukum, Bandung: PT. Citra Aditya Bakti

Saifuddin Azwar, 2014, Metode Penelitian, Yogyakarta: Pustaka Pelajar

Soerjono Soekanto and Sri Mamudji, 1985, Penelitian Hukum Normatif, Suatu Tinjauan Singkat, Jakarta: Raja Grafindopersada

Regulation

Act No. 2 of 2002 concerning the Indonesian National Police

Republic of Indonesia Government Regulation Number 2 of 2003 concerning Disciplinary Regulations for Members of the National Police

Chief of Police Regulation No.Pol. 14 of 2011 concerning the Professional Code of Ethics for the State Police of the Republic of Indonesia. 